\title{
Vulnerability and adaptive capacity of smallholders in Ho Ho sub-watershed, north-central Viet Nam
}

Rachmat Mulia, Bac Viet Dam, Delia Catacutan 



\section{Vulnerability and adaptive capacity of smallholders in Ho Ho sub-watershed, north-central Viet Nam}

Rachmat Mulia, Bac Viet Dam and Delia Catacutan

Working paper no. 217 


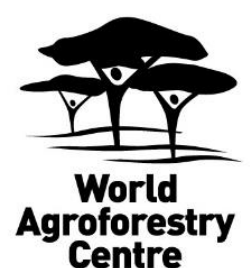

\section{Correct Citation}

Mulia R, Dam VB, Catacutan D. 2015. Vulnerability and adaptive capacity of smallholders in Ho Ho subwatershed, north-central Viet Nam. Working paper 217. Ha Noi, Viet Nam: World Agroforestry Centre (ICRAF) Southeast Asia Regional Program. DOI: http://dx.doi.org/10.5716/WP15728.PDF

Titles in the Working Paper Series aim to disseminate interim results on agroforestry research and practices and stimulate feedback from the scientific community. Other publication series from the World Agroforestry Centre include: agroforestry perspectives, technical manuals and occasional papers.

Published by the World Agroforestry Centre (ICRAF)

Viet Nam Country Office

No. 17A Nguyen Khang street, Trung Hoa ward, Cau Giay district

Ha Noi, Viet Nam

Tel: +844 33783 4644/5

Fax: +844 33783 4644/5

Internet: www.worldagroforestry.org/regions/southeast_asia/vietnam

(C) World Agroforestry Centre 2015

Working Paper no. 217

\section{Disclaimer and copyright}

The views expressed in this publication are those of the author(s) and not necessarily those of the World Agroforestry Centre. Articles appearing in this publication may be quoted or reproduced without charge, provided the source is acknowledged. All images remain the sole property of their source and may not be used for any purpose without written permission of the source. 


\section{About the authors}

Rachmat Mulia is a statistician and modeller. He has a $\mathrm{PhD}$ from Montpellier University, France and more than 10 years' experience in modelling tree and crop interactions in agroforestry systems and analysing trade-offs between environmental services, household incomes and food security during land-use changes. He is currently analysing data of smallholders' vulnerability and the role of trees in livelihoods and environmental services and modelling simulations of river flow in central Viet Nam.

Bac Viet Dam is a researcher and the research manager of the Climate-smart, Tree-based, Coinvestment in Adaptation and Mitigation in Asia project, co-funded by the International Fund for Agricultural Development and the CGIAR Research Program on Forests, Trees and Agroforestry and implemented by the World Agroforestry Centre in Viet Nam. He holds a Master of Science in Forest Resources Management and Social Forestry from the University of the Philippines, Los Baños and has wide experience in research and development activities in Viet Nam. His research includes reducing emissions from forest degradation and deforestation, payments for environmental services and climate-change adaptation.

Delia Catacutan is a senior social scientist at the World Agroforestry Centre in Viet Nam, with over 10 years' experience in policy and institutional research in integrated natural resource management. Dr Catacutan is also the Centre's Viet Nam program coordinator and the focal point for gender research and capacity building. She has extensive experience working in interdisciplinary research projects, including smallholders' incentives for providing ecosystem services, linking knowledge with action, institutional innovation, collective action and property rights, and technology adoption in Asia and Africa. She was a post-doctoral fellow at the Sustainability Science Program at Harvard University's Center for International Development. She holds a PhD in Natural and Rural Systems Management from the University of Queensland, Australia. 


\section{Abstract}

Climate change and variability create large uncertainties for agricultural production and smallholders' livelihoods. Understanding smallholders' vulnerability and their adaptive capacity to these factors is the key to appropriate interventions to mitigate the impact of climate-related shocks and hazards. In Ho Ho sub-watershed, north-central Viet Nam, smallholders reported a high degree of exposure and sensitivity to climate change and variability owing to the frequency of weather-related extreme events, such as flooding and drought, during the last decade (2005-2014), with a concomitant impact on households and agriculture. When comparing up- and downstream communes, biophysical factors such as topography, land-use patterns and the presence of a hydropower plant in the downstream commune played important roles in creating differences in exposure, sensitivity and adaptive capacity between the two communes. The results showed that while the upstream commune was not more vulnerable to weather-related extreme events compared to the downstream, its adaptive capacity was much lower, making the upstream generally more vulnerable than the downstream commune. We concluded that serious effects of climate change and variability during the last decade were experienced by smallholders in Ho Ho sub-watershed. We recommend that while enhancing the adaptive capacity of smallholders can include improvement both on- and off-farm, growing trees is a solution for improving both the landscapes and smallholders' resilience.

Keywords: Adaptive capacity, central Viet Nam, extreme weather events, sub-watershed, vulnerability 


\section{Acknowledgements}

The study was conducted under the Climate-Smart, Tree-Based, Co-Investment in Adaptation and Mitigation in Asia project, co-funded by the International Fund for Agriculture Development and the CGIAR Research Program on Forests, Trees and Agroforestry. Thanks are addressed particularly to local partners in the districts of Huong Khe, Ha Tinh province and Tuyen Hoa, Quang Binh province for conducting the household surveys and focus-group discussions in the upstream and downstream commune of the Ho Ho sub-watershed. 


\section{Contents}

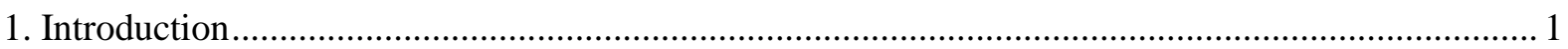

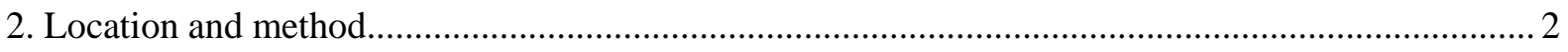

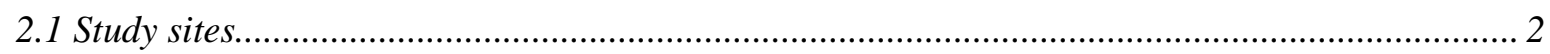

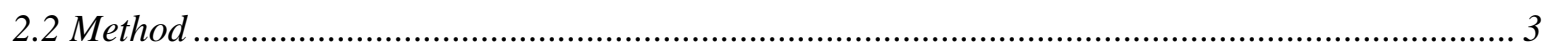

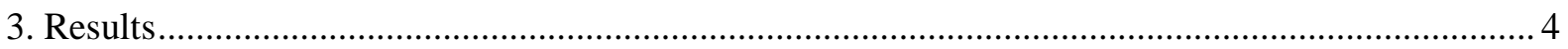

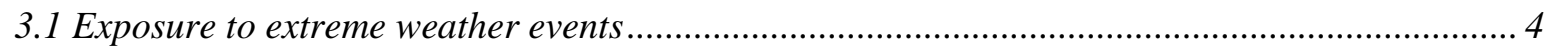

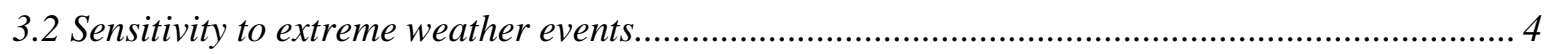

3.3 Adaptive capacity to extreme weather events ……................................................................ 5

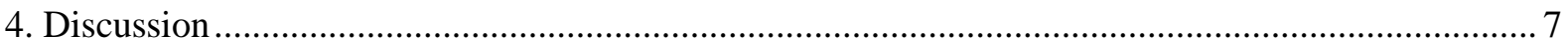

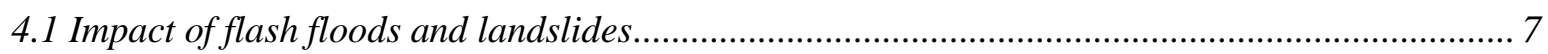

4.2 Adaptive capacity to mitigate impact of extreme weather events ................................................ 7

4.3 Possible interventions to mitigate effect of flooding and landslides ............................................ 8

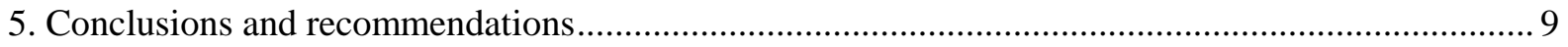

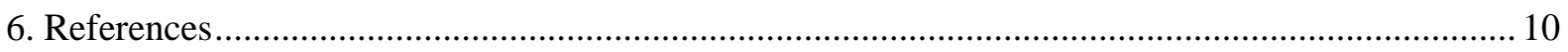




\section{List of Figures}

Figure 1. Location of Ho Ho sub-watershed in north-central Viet Nam................................................ 2

Figure 2. a) Years in the last decade (2005-2014) when extreme events occurred; and b) the frequency of occurrences within the studied years according to local knowledge.

Figure 3. a) Proportion of households; and b) plots of annual crops affected by extreme events, according to local knowledge

Figure 4. Landholding per household in the upstream and downstream communes in 2014 represented by a) the average number of plots; and b) average land size.

Figure 5. Average household incomes in the upstream and downstream communes in 2014 from various a) on-farm; and b) off-farm sources.

Figure 6. a) Percentage of smallholders with savings in 2014; b) average years of schooling; and c) total number of household members, based on local knowledge, in the upstream and downstream communes

Figure 7. Relative land-cover area in 2014 , based on satellite images, in the a) upstream; and b) downstream communes . 



\section{Introduction}

Climate variability and long-term changes has a diverse impact on the hydrology of watersheds through increasing the risk of floods, drought sand landslides and negatively affect agricultural production and human livelihoods (Devkota and Gwayali 2015). These effects will be felt mostly by the poor in rural communities, whose livelihoods are largely reliant on agricultural and natural resources (Chen et al 2013, Jamir et al 2012). Biophysical shocks and hazards caused by natural processes are usually intertwined with socio-economic and political ones (Dewi et al 2013a).

The Intergovernmental Panel on Climate Change (IPCC) defines vulnerability as 'the degree to which a system is susceptible to, or unable to cope with, adverse effects of climate change, including climate variability and weather-related extreme events, and it is a function of the character, magnitude, and rate of climate variation to which a system is exposed, its sensitivity, and its adaptive capacity' (IPCC 2001). The term exposure refers to the 'nature and degree to which a system is exposed to significant climatic variations' whereas sensitivity is 'the degree to which a system is affected, either adversely or beneficially, by climate-related stimuli'. Adaptive capacity is defined as 'the ability of a system to adjust to climate change (including variability and extreme events) to moderate potential damages, to take advantage of opportunities, or to cope with the consequences'. Van Noordwijk et al (2011) stated that vulnerability depends on the buffering capacity of the landscape and its inhabitants as well as the intensity of a shock or hazard that might exceed the buffering capacity. While shocks or hazards cannot be controlled, potentially buffering capacity can be.

Depending on the study area, assessments of vulnerability range from global and national scales to the local, using qualitative participatory approaches (IPCC 2012). In order to capture the different aspects and complexities of vulnerability, both qualitative and quantitative approaches should be conducted.

In Viet Nam, some studies have already reported the impact of climate change and variability on multiple sectors (Asian Development Bank 2013). However, these studies were mostly conducted at the national level. A focus on local conditions, based on local knowledge, is rare (for example, Simelton et al 2015). Local perceptions of climate variability and extreme weather events include understanding the causes, characteristics and impact on livelihoods as well as the adaptive capacity and strategies of the people. Understanding local perceptions of vulnerability to climate change is the key to developing appropriate interventions for enhancing adaptive capacity of smallholders (Bhave et al 2013). Among different interventions, a long-term strategy that provides preventive measures, rather than survival efforts after a shock, is more effective (Dewi et al 2013b).

In this working paper, we present knowledge about the vulnerability and adaptive capacities of smallholders in Ho Ho sub-watershed, Ha Tinh province, north-central Viet Nam. Specifically, we compare the exposure, sensitivity and adaptive capacity of the smallholders in the up- and downstream areas of the sub-watershed. Our hypothesis was that owing to differences in biophysical conditions, such as topography, land-use mosaic and the presence of a hydropower plant in the downstream commune of the sub-watershed, the degree of vulnerability in the up- and downstream communes would be different and be reflected in local knowledge. We make some recommendations to improve local resilience to climate variability. 


\section{Location and method}

\subsection{Study sites}

The Ho Ho sub-watershed (Figure 1) is located between $105^{\circ} 42^{\prime} 16.49^{\prime \prime} \mathrm{E}$ and $18^{\circ} 5{ }^{\prime} 25.41^{\prime \prime} \mathrm{N}$ within the administrative boundaries of Huong Khe district of Ha Tinh province and Tuyen Hoa district of Quang Binh province, north-central Viet Nam. The 2014 population was 10,000 people (equivalent to 3500 households). The average population density was 41.5 people per $\mathrm{km}^{2}$ in the upstream (Huong Lam and Huong Lien) commune and 30.2 people per $\mathrm{km}^{2}$ in the downstream (Huong Hoa) commune. The hydrology in the sub-watershed largely depends on two main rivers, namely Ngan Sau and Rao Boi, that flow across the sub-watershed. A dense stream system and high elevation in the upstream accelerate surface flow, especially in the rainy season between August and October.

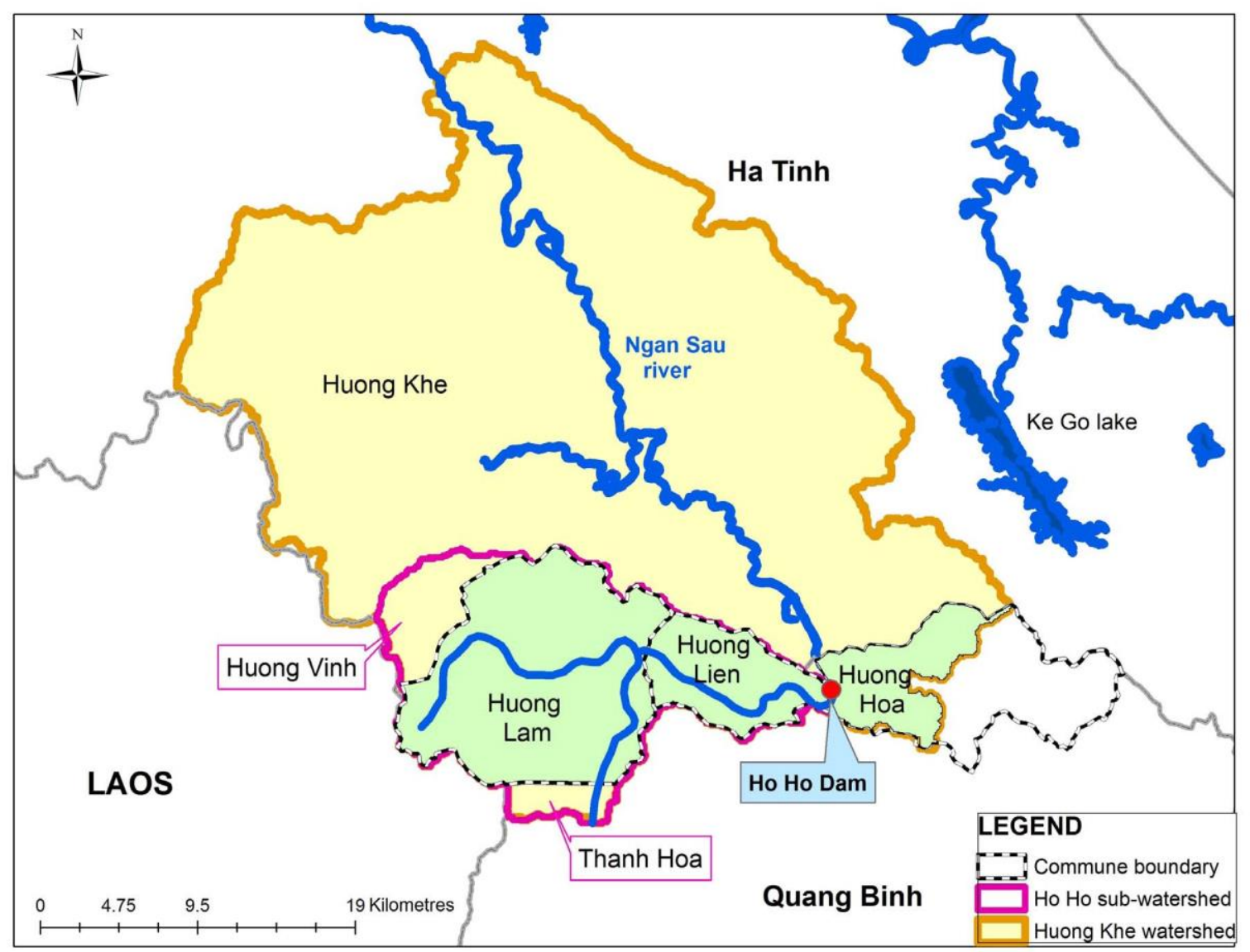

Figure 1. Location of Ho Ho sub-watershed in north-central Viet Nam

The sub-watershed is influenced by the tropical monsoon both in the summer and winter seasons. Summer generally starts from April to August with low humidity. In particular, the area is largely affected by a southwestern wind in June and July. Winter extends from November to March with the northeastern monsoon and rainfall. Based on the 1982-2011 weather data record of Huong Khe district obtained from the Institute of Meteorology, Hydrology and Climate Change, the average temperature in the area was $25^{\circ} \mathrm{C}$ with $28.7^{\circ} \mathrm{C}$ as the average maximum and $21.2^{\circ} \mathrm{C}$ the average 
minimum. The average annual rainfall was $2500 \mathrm{~mm}$. The rainy season falls between August and September with average total rainfall of $1425 \mathrm{~mm}$, equivalent to $60 \%$ of the region's annual rainfall. January and February are the driest months, with average total monthly rainfall of $96.6 \mathrm{~mm}$. The topography of the sub-watershed is dominated by rivers and streams.

The study site includes two villages in Huong Lam (upstream commune) and three villages in Huong Hoa (downstream commune) of the Ho Ho sub-watershed. The village selection was preceded by consultation with district and commune officials to cover spatial variation in water scarcity and impact of weather-related extreme events, such as floods, drought, storms, cold spells and landslides. Since 2013, Ho Ho hydropower plant, located on the border of the middle and downstream communes, has provided electricity and irrigation for the downstream commune. Construction began in 2004 to intercept water flow from Ngan Sau River. The hydropower plant draws on $276 \mathrm{~km}^{2}$ of the basin and features $2.35 \mathrm{~km}^{2}$ of reservoir. The average annual flow is $19.6 \mathrm{~m}^{3} \mathrm{~s}^{-1}$ with a full capacity of 38 million $\mathrm{m}^{3}$. Estimated average annual electricity output is 54 million $\mathrm{kWh}$.

\subsection{Method}

In our study, exposure was represented by the number of years in the last decade (2005-2014) the sub-watershed was affected by extreme weather events and the number of those occurrences.

Sensitivity was measured by the number of affected households and plots of annual crops with wet rice ('paddy') and maize as the main annual crops. Adaptive capacity was measured by the size of the landholding, on-and off/non-farm income, years of schooling, number of family members and amount of savings.

Local knowledge of exposure and sensitivity to weather-related extreme events was captured through focus-group discussions conducted in 2014 , with two separate female and two separate male groups in both the up- and downstream commune of the Ho Ho sub-watershed. Local knowledge was defined as 'a collection of facts that relates to the entire system of concepts, beliefs and perceptions that people hold about the world around them. This includes the way people observe and measure their surroundings, how they solve problems and validate new information. It includes the processes whereby knowledge is generated, stored, applied and transmitted to others' (FAO 2004). Each group consisted of five people to total 10 female and 10 male respondents per commune. The respondents were sampled from different villages in the communes and the groups were interviewed separately in the commune office to ensure independence between groups. Data for examining adaptive capacity were gathered through a household survey in 2014 that covered 100 households in the upstream and 100 households in the downstream commune. A stratified random design was applied to sample households from different villages in the communes. 


\section{Results}

\subsection{Exposure to extreme weather events}

According to local knowledge, in the last decade storm occurrence was more frequent in the upstream than downstream commune (Figure 2a). An inverse trend was observed for landslides. Landslides were clearly more frequent in the downstream than the upstream. The presence of the Ho Ho dam likely induced more landslides in the downstream commune. For other extreme weather events, like drought and cold, no clear differences in occurrence was found between the two communes (Figure 2a). Locals reported slightly more frequent flash floods in the upstream commune.

In the upstream, on average, four flooding events occurred within the studied years (Figure 2b). This was almost double the frequency of floods in the downstream commune. More rivers in the upstream and their proximity to settlements most likely made more frequent flooding noticeable by smallholders. Storms and cold spells were reported to occur more often within a year in the downstream than the upstream (Figure 2b). Interestingly, although in the last decade landslides occurred more frequently in the downstream, the frequency within a year was higher in the upstream than the downstream (Figure 2b).

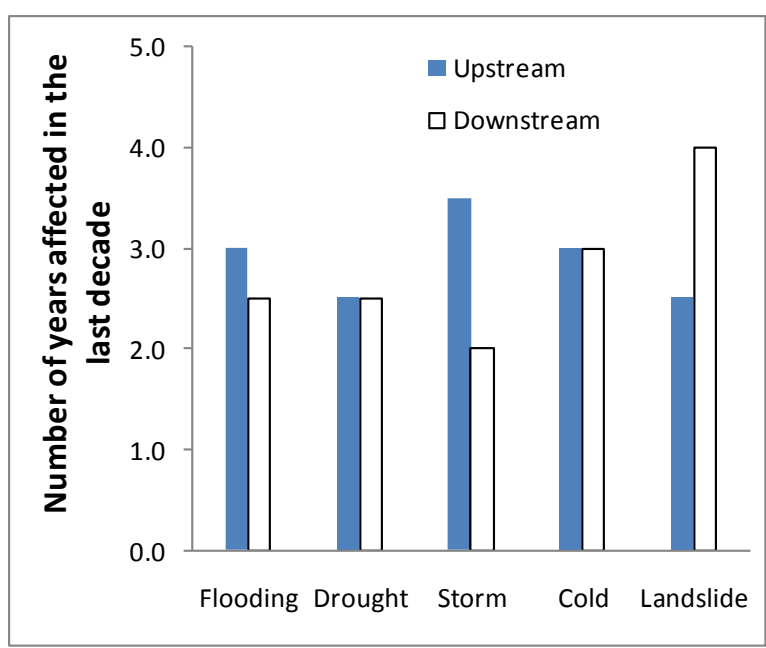

(a)

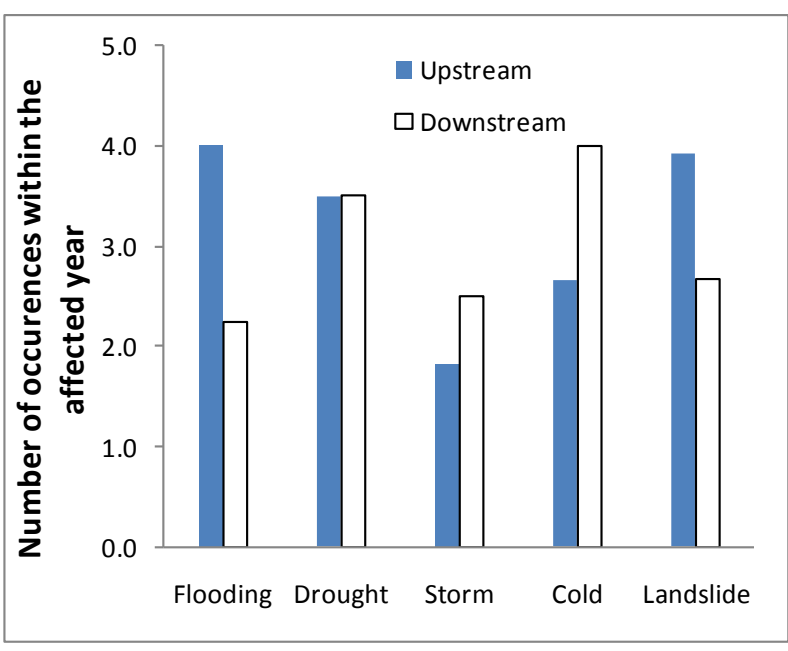

(b)

Figure 2. a) Years in the last decade (2005-2014) when extreme events occurred; and b) the frequency of occurrences within the studied years according to local knowledge

\subsection{Sensitivity to extreme weather events}

The effect of flash floods on households was reported to be more severe in the upstream than the downstream commune (Figure 3a). This is not surprising since flash floods occurred more often during the last decade and more frequently within a year in the upstream. Storms and landslides affected more households in the downstream than upstream (Figure 3a). For landslides, the presence of the Ho Ho dam likely induced a stronger impact on the downstream commune. 
Flash floods and landslides caused serious damage to plots of annual crops in the downstream (Figure $3 b$ ). On average, about $82 \%$ (from landslides) and $70 \%$ (from floods) of the total area under annual crops in the downstream commune were damaged each time either event occurred.

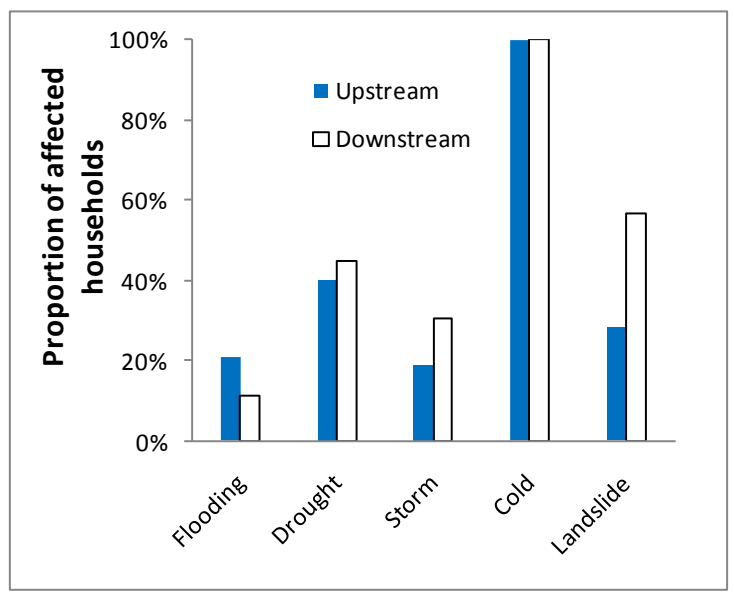

(a)

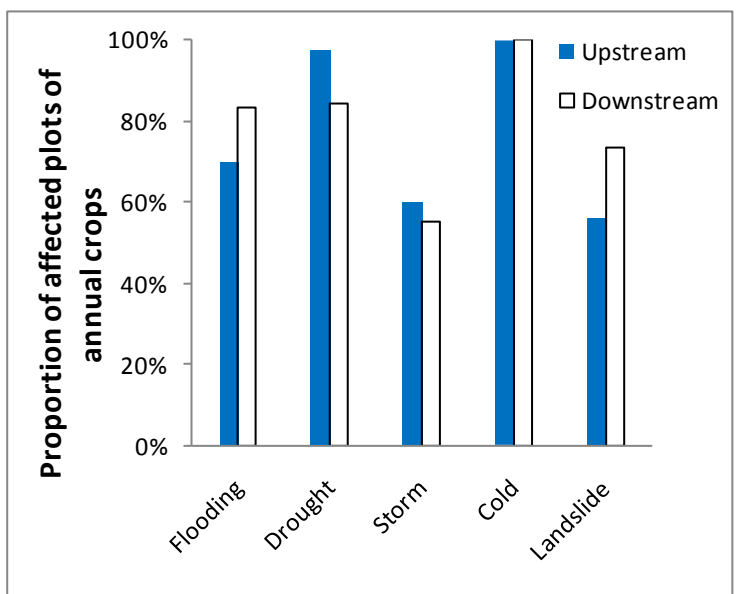

(b)

Figure 3. a) Proportion of households; and b) plots of annual crops affected by extreme events, according to local knowledge

\subsection{Adaptive capacity to extreme weather events}

Smallholders in the downstream commune cultivated more plots of wet rice and annual crops compared to those in the upstream (Figure 4a). The average number of plots of wet rice and annual crops per household in the downstream were 3.2 and 2.8, respectively, but were scattered in different locations of relatively small area. In terms of area, the dominant landuse was production or planted forest in the form of acacia plantation for pulp (Figure $4 \mathrm{~b}$ ). Both in the upstream and downstream, on average, the size of landholdings for production or planted forest was more than 1 ha per household (Figure $4 \mathrm{~b}$ ). For other land-use types, such as wet rice, annual crops and homegardens, on average, the size of the landholding per household was larger in the downstream than the upstream commune. 


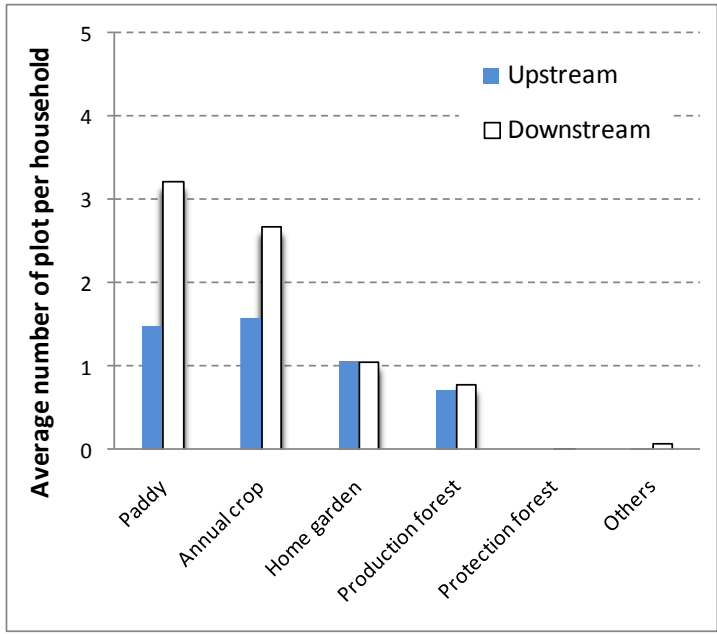

(a)

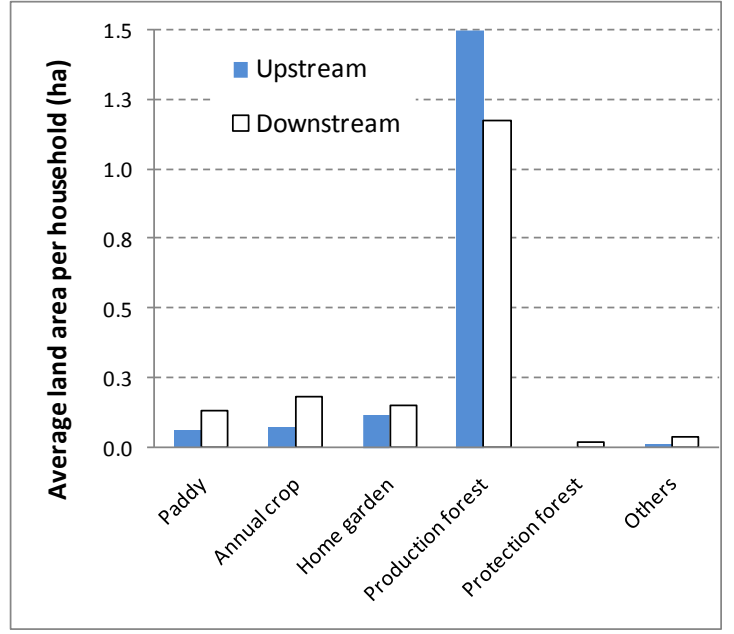

(b)

Figure 4. Landholding per household in the upstream and downstream communes in 2014 represented by a) the average number of plots; and b) average land size.

For smallholders in the downstream, the contribution to their incomes from annual crops and production forests was more significant than that from wet rice or homegardens (Figure 5a). Interestingly, although in terms of number of plots and land size, wet rice in the downstream was more dominant than in the upstream, income from wet rice was much lower in the downstream than the upstream. This was because the rice productivity rate in the downstream was lower than in the upstream, possibily owing to water shortages and a higher portion of production used for private consumption. Income from various off-/non-farm sectors was clearly higher, with more options available, in the downstream than the upstream (Figure 5b).

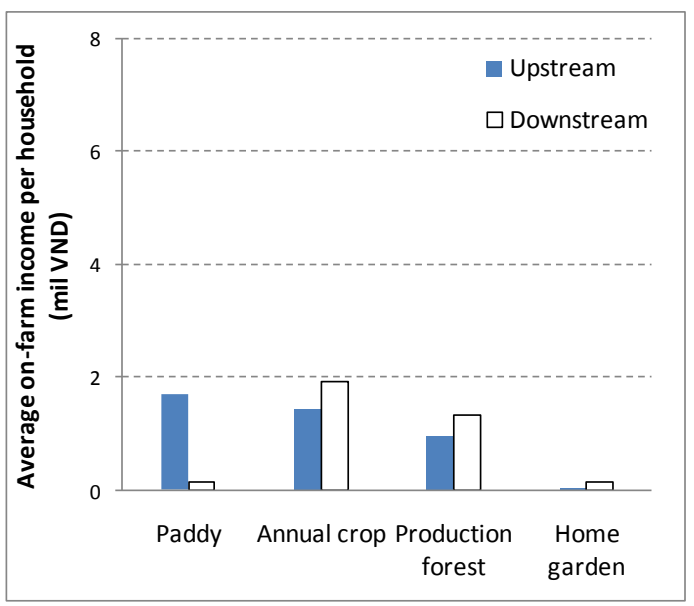

(a)

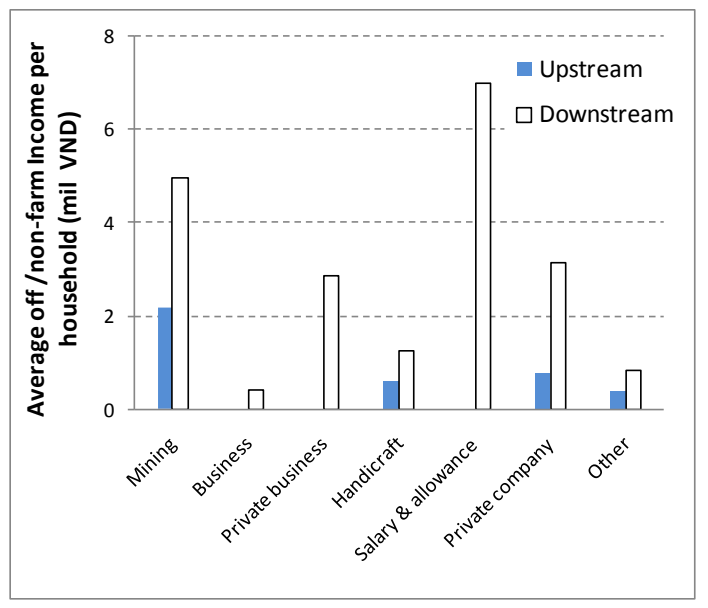

(b)

Figure 5. Average household incomes in the upstream and downstream communes in 2014 from various a) onfarm; and b) off/non-farm sources

In 2014, only $10 \%$ of the sampled households in the downstream had savings (Figure 6a). This included money saved as cash by individuals, with non-family members or in the local bank. In the 
upstream, the percentage was much lower (around 2\%), most likely linked to lower annual incomes in this communes. In terms of education, on average, locals in the upstream and downstream both had about 7.5 years of schooling (Figure 6b). The average number of total household members was comparable between the upstream and downstream, with about four people per household (Figure 6c). The figure only takes into account family members living in the same house.

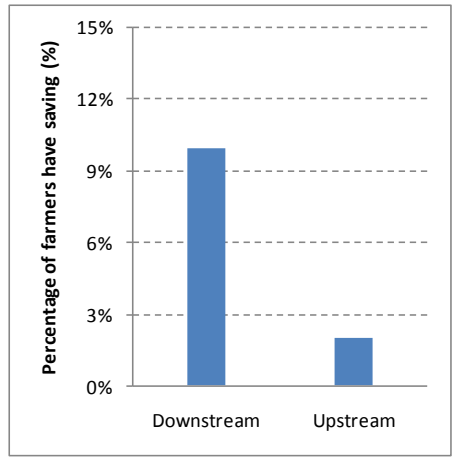

(a)

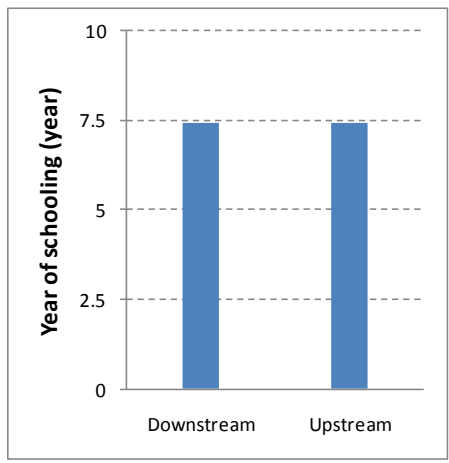

(b)

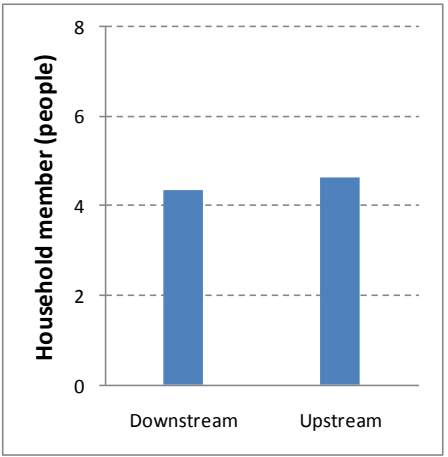

(c)

Figure 6. a) Percentage of smallholders with savings in 2014;b) average years of schooling; and c) total number of household members, based on local knowledge, in the upstream and downstream communes

\section{Discussion}

\subsection{Impact of flash floods and landslides}

Of all the extreme weather events, only flash floods and landslides wreaked differing impacts on the upstream and downstream communes. More rivers running through the upstream commune, at closer distances to settlements, affected more households through flash floods. Annual crops, however, were more affected in the downstream than the upstream commune, which was most likely related to the presence of the hydropower plant. The dam is situated at a higher elevation, about $75 \mathrm{~m}$ above the downstream land, and releases water to the commune for around seven hours per day in a normal season, through two turbines. During the rainy season, usually between August and October, heavy flow into the dam is usually managed by longer dam and turbine operation times but, nevertheless, the continuously strong flow out of the dam brings flash floods and landslides to households and plots of annual crops. Owing to the destructive effect of floods in both the upstream and downstream, locals generally cannot cultivate annual crops situated within $100 \mathrm{~m}$ of both sides of the riverbanks. Flash floods are also the main constraint to planting trees along riverbanks. Communication with key informants in the communes revealed that locals only see concrete construction as a way to overcome landslides along riverbanks.

\subsection{Adaptive capacity to mitigate impact of extreme weather events}

Income, savings, education level and number of household members are four variables proportional to adaptive capacity. On-farm income from wet rice, other annual crops, production or planted forests 
and homegardens was relatively the same between downstream and upstream. Off/non-farm income, however, was higher in the downstream where jobs were more available. Most likely, this also contributed to the number of smallholders who had savings in 2014, which was about $10 \%$ and $2 \%$ in the downstream and upstream, respectively, of the total populations in the communes. Based on household incomes and savings in 2014, smallholders in the downstream commune had a higher adaptive capacity than those in the upstream.

\subsection{Possible interventions to mitigate effect of flooding and landslides}

Interviews with informants represented by commune/village leaders and representatives from the local Department of Agriculture and Rural Development as well as with smallholders revealed that the key to mitigating the effects of flash floods and landslides was to improve the quality of natural forests, especially in upstream. In 2014, the area of poor natural forests (logged-over forests) in the upstream and downstream were $72 \%$ and 69\%, respectively (Figure 7a, b). Locals claimed that forest restoration was beyond their authority since natural forests were managed by a state body called Ngan Sau Forest Management Board.

Negotiation with the forest management board is critical, especially given plans to convert poor natural forests into monocultural acacia plantations rather than conserving the areas for forest restoration. A 'payment for forest environmental services' scheme is necessary, along with forest restoration, that involves the various stakeholders in the sub-watershed. Interviews with the Ho Ho dam's management board also confirmed the need to restore upstream forests to mitigate the effects of flash floods and landslides. They also mentioned the need to plant trees along both sides of riverbanks. This, however, can be done following restoration of upstream forests since planting along riverbanks is not possible when severe flash floods still occurs during the rainy season, damaging areas within $100 \mathrm{~m}$ of both sides of the banks. A detailed land-cover analysis in Ho Ho sub-watershed can be seen in Nguyen et al (2015).

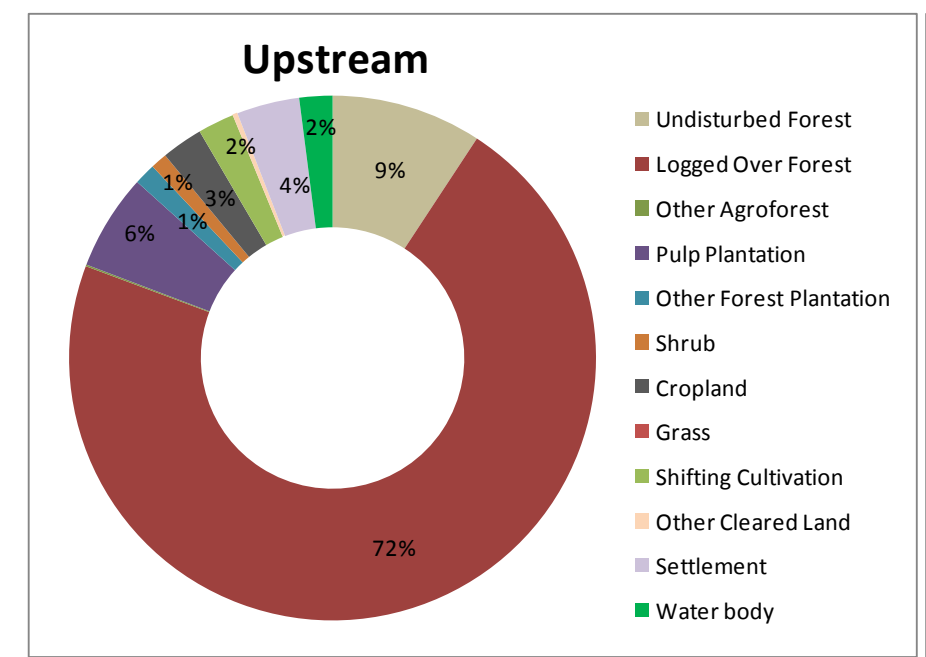

(a)

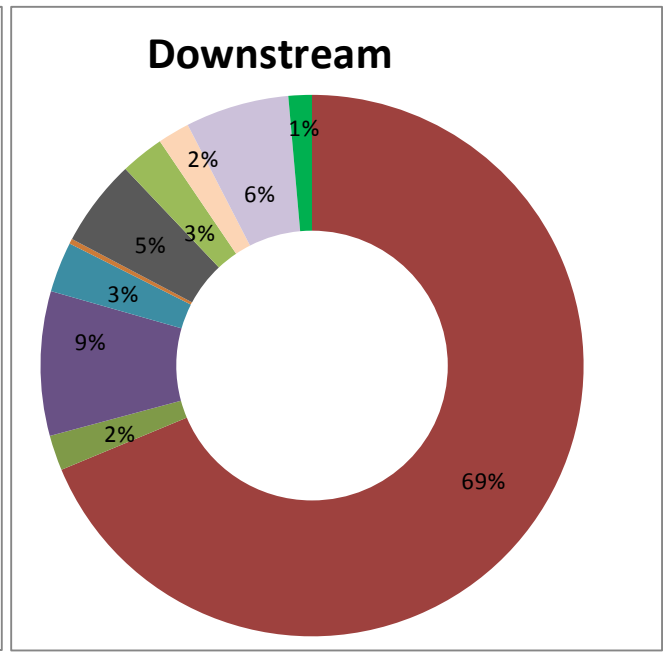

(b)

Figure 7. Relative land-cover area in 2014, based on satellite images, in the a) upstream; and b) downstream communes 


\section{Conclusions and recommendations}

Serious impact of climate change and variability during the last decade were experienced by smallholders in Ho Ho sub-watershed. Taking into consideration analysis of exposure and sensitivity data, we cannot conclude that the upstream commune experienced more frequent and stronger destructive impact of extreme weather events compared to the downstream but the adaptive capacity of smallholders in the upstream was much lower, making the upstream commune generally more vulnerable than the downstream.

Among other efforts to mitigate the impact and enhance resilience of smallholders to climate change and variability - such as increasing off/non-farm income - we would like to highlight the important role of trees in enhancing both the socio-economic and environmental resilience of smallholders in Ho Ho sub-watershed. Trees are important sources of longer-term and stable income and can modify micro-climates. At a larger scale, they improve environmental services in a landscape, such as the capacity to store water in soils. Communication with smallholders indicated enrichment with trees in poor natural forests as the main solution but planting trees in plots of annual crops and homegardens would also contribute to increased resilience to climate change and variability.

In other working papers, we will describe the use of a simulation model to assess the impact of forest restoration on hydrology in the sub-watershed and discuss a study that identified local knowledge ofthe role trees play in livelihoods and the environment, in both the upstream and downstream communes of the sub-watershed. 


\section{References}

Asian Development Bank. 2013. Viet Nam environment and climate change assessment. Manila: Asia Development Bank. http://www.adb.org/sites/default/files/institutional-document/33916/files/viet-namenvironment-climate-change.pdf

Bhave AG, Mishra A, Groot A. 2013. Sub-basin scale characterization of climate change vulnerability, impacts and adaptation in an Indian River basin.Regional Environmental Change 13:1087-1098. DOI 10.1007/s10113-013-0416-8.

Chen NS, Hu GS, Deng W, Khanal N, Zhu YH, Han D. 2013. On the water hazards in the trans-boundary Kosi River basin. Natural Hazards and Earth Systems Science 13:795-808.

Devkota LP, Gyawali DR. 2015. Impacts of climate change on hydrological regime and water resources management of the Koshi River Basin, Nepal. Journal of Hydrology: Regional Studies4:502-515.

Dewi S, Khasanah N, Widayati A. 2013a. Capacity-strengthening approach to vulnerability assessment. In: van Noordwijk M, Lusiana B, Leimona B, Dewi S, Wulandari, eds. Negotiation-support toolkit for learning landscapes. Bogor, Indonesia: World Agroforestry Centre (ICRAF) Southeast Asia Regional Program. pp 234-238.

Dewi S, Martini E, Janudianto. 2013b. Tree and farming system resilience to climate change and market fluctuations (Treesilience). In: van Noordwijk M, Lusiana B, Leimona B, Dewi S, Wulandari, eds. Negotiation-support toolkit for learning landscapes. Bogor, Indonesia: World Agroforestry Centre (ICRAF) Southeast Asia Regional Program. pp 83-89.

Food and Agriculture Oganization. 2004. What is local knowledge? In: Building on gender, agrobiodiversity and local knowledge: a training manual. Rome: Food and Agriculture Organization of the United Nations.

[IPCC] Intergovernmental Panel on Climate Change. 2001. Synthesis report. A contribution of working groups I, II and III to the third assessment report of the intergovernmental panel on climate change. Cambridge, UK: Cambridge University Press. http://www.grida.no/publications/other/ipcc_tar/

[IPCC] Intergovernmental Panel on Climate Change. 2012. Managing the risks of extreme events and disasters to advance climate change adaptation. In: Field CB, Barros V, Stocker TF, Qin D, Dokken DJ, Ebi KL, Mastrandrea MD, Mach KJ, Plattner GK, Allen SK, Tignor M, MidgleyPM, eds. A special report of working groups I and II of the Intergovernmental Panel on Climate Change. Cambridge, UK: Cambridge University Press. https://www.ipcc.ch/pdf/special-reports/srex/SREX_Full_Report.pdf

Jamir C, Sharma N, Sengupta A, Ravindranath NH. 2012. Farmers' vulnerability to climate variability in Dimapur district of Nagaland, India. Regional Environmental Change 13(1):153-164. DOI 10.1007/s10113-012-0324-3.

Nguyen MP, Dam VB, Ngo DA, Mulia R. 2015. Landuse/cover change in Ho Ho sub-watershed, northern central Viet Nam. Working paper No. 219. Ha Noi, Viet Nam: World Agroforestry Centre (ICRAF) Southeast Asia Regional Program.

Van Noordwijk M, Hoang MH, Neufeldt H, Oborn I, Yatich T. 2011. How trees and people can co-adapt to climate change: reducing vulnerability through multifunctional agroforestry landscapes. Nairobi: World Agroforestry Centre (ICRAF).

Simelton E, Dam VB, Catacutan D. 2015. Trees and agroforestry for coping with extreme weather events: experiences from northern and central Viet Nam. Agroforestry Systems 89(6): 1065-1082. DOI 10.1007/s10457-015-9835-5. 


\section{WORKING PAPERS WITH DOIS}

\section{5}

1. Agroforestry in the drylands of eastern Africa: a call to action

2. Biodiversity conservation through agroforestry: managing tree species diversity within a network of community-based, nongovernmental, governmental and research organizations in western Kenya.

3. Invasion of prosopis juliflora and local livelihoods: Case study from the Lake Baringo area of Kenya

4. Leadership for change in farmers organizations: Training report: Ridar Hotel, Kampala, 29th March to 2nd April 2005.

5. Domestication des espèces agroforestières au Sahel : situation actuelle et perspectives

6. Relevé des données de biodiversité ligneuse: Manuel du projet biodiversité des parcs agroforestiers au Sahel

7. Improved land management in the Lake Victoria Basin: TransVic Project's draft report.

8. Livelihood capital, strategies and outcomes in the Taita hills of Kenya

9. Les espèces ligneuses et leurs usages: Les préférences des paysans dans le Cercle de Ségou, au Mali

10. La biodiversité des espèces ligneuses: Diversité arborée et unités de gestion du terroir dans le Cercle de Ségou, au Mali

\section{6}

11. Bird diversity and land use on the slopes of Mt. Kilimanjaro and the adjacent plains, Tanzania

12. Water, women and local social organization in the Western Kenya Highlands

13. Highlights of ongoing research of the World Agroforestry Centre in Indonesia

14. Prospects of adoption of tree-based systems in a rural landscape and its likely impacts on carbon stocks and farmers' welfare: The FALLOW Model Application in Muara Sungkai, Lampung, Sumatra, in a 'Clean Development Mechanism' context

15. Equipping integrated natural resource managers for healthy Agroforestry landscapes.

17. Agro-biodiversity and CGIAR tree and forest science: approaches and examples from Sumatra.

18. Improving land management in eastern and southern Africa: A review of policies.

19. Farm and household economic study of Kecamatan Nanggung, Kabupaten Bogor, Indonesia: A socioeconomic base line study of Agroforestry innovations and livelihood enhancement.

20. Lessons from eastern Africa's unsustainable charcoal business.

21. Evolution of RELMA's approaches to land management: Lessons from two decades of research and development in eastern and southern Africa

22. Participatory watershed management: Lessons from RELMA's work with farmers in eastern Africa.

23. Strengthening farmers' organizations: The experience of RELMA and ULAMP.

24. Promoting rainwater harvesting in eastern and southern Africa.

25. The role of livestock in integrated land management.

26. Status of carbon sequestration projects in Africa: Potential benefits and challenges to scaling up.

27. Social and Environmental Trade-Offs in Tree Species Selection: A Methodology for Identifying Niche Incompatibilities in Agroforestry [Appears as AHI Working Paper no. 9]

28. Managing tradeoffs in agroforestry: From conflict to collaboration in natural resource management. [Appears as AHI Working Paper no. 10]

29. Essai d'analyse de la prise en compte des systemes agroforestiers pa les legislations forestieres au Sahel: Cas du Burkina Faso, du Mali, du Niger et du Senegal.

30. Etat de la recherche agroforestière au Rwanda etude bibliographique, période 1987-2003 
31. Science and technological innovations for improving soil fertility and management in Africa: A report for NEPAD's Science and Technology Forum.

32. Compensation and rewards for environmental services.

33. Latin American regional workshop report compensation.

34. Asia regional workshop on compensation ecosystem services.

35. Report of African regional workshop on compensation ecosystem services.

36. Exploring the inter-linkages among and between compensation and rewards for ecosystem services CRES and human well-being

37. Criteria and indicators for environmental service compensation and reward mechanisms: realistic, voluntary, conditional and pro-poor

38. The conditions for effective mechanisms of compensation and rewards for environmental services.

39. Organization and governance for fostering Pro-Poor Compensation for Environmental Services.

40. How important are different types of compensation and reward mechanisms shaping poverty and ecosystem services across Africa, Asia \& Latin America over the Next two decades?

41. Risk mitigation in contract farming: The case of poultry, cotton, woodfuel and cereals in East Africa.

42. The RELMA savings and credit experiences: Sowing the seed of sustainability

43. Yatich J., Policy and institutional context for NRM in Kenya: Challenges and opportunities for Landcare.

44. Nina-Nina Adoung Nasional di So! Field test of rapid land tenure assessment (RATA) in the Batang Toru Watershed, North Sumatera.

45. Is Hutan Tanaman Rakyat a new paradigm in community based tree planting in Indonesia?

46. Socio-Economic aspects of brackish water aquaculture (Tambak) production in Nanggroe Aceh Darrusalam.

47. Farmer livelihoods in the humid forest and moist savannah zones of Cameroon.

48. Domestication, genre et vulnérabilité : Participation des femmes, des Jeunes et des catégories les plus pauvres à la domestication des arbres agroforestiers au Cameroun.

49. Land tenure and management in the districts around Mt Elgon: An assessment presented to the Mt Elgon ecosystem conservation programme.

50. The production and marketing of leaf meal from fodder shrubs in Tanga, Tanzania: A pro-poor enterprise for improving livestock productivity.

51. Buyers Perspective on Environmental Services (ES) and Commoditization as an approach to liberate ES markets in the Philippines.

52. Towards Towards community-driven conservation in southwest China: Reconciling state and local perceptions.

53. Biofuels in China: An Analysis of the Opportunities and Challenges of Jatropha curcas in Southwest China.

54. Jatropha curcas biodiesel production in Kenya: Economics and potential value chain development for smallholder farmers

55. Livelihoods and Forest Resources in Aceh and Nias for a Sustainable Forest Resource Management and Economic Progress

56. Agroforestry on the interface of Orangutan Conservation and Sustainable Livelihoods in Batang Toru, North Sumatra. 
57. Assessing Hydrological Situation of Kapuas Hulu Basin, Kapuas Hulu Regency, West Kalimantan.

58. Assessing the Hydrological Situation of Talau Watershed, Belu Regency, East Nusa Tenggara.

59. Kajian Kondisi Hidrologis DAS Talau, Kabupaten Belu, Nusa Tenggara Timur.

60. Kajian Kondisi Hidrologis DAS Kapuas Hulu, Kabupaten Kapuas Hulu, Kalimantan Barat.

61. Lessons learned from community capacity building activities to support agroforest as sustainable economic alternatives in Batang Toru orang utan habitat conservation program (Martini, Endri et al.)

62. Mainstreaming Climate Change in the Philippines.

63. A Conjoint Analysis of Farmer Preferences for Community Forestry Contracts in the Sumber Jaya Watershed, Indonesia.

64. The highlands: a shared water tower in a changing climate and changing Asia

65. Eco-Certification: Can It Deliver Conservation and Development in the Tropics.

66. Designing ecological and biodiversity sampling strategies. Towards mainstreaming climate change in grassland management.

67. Towards mainstreaming climate change in grassland management policies and practices on the Tibetan Plateau

68. An Assessment of the Potential for Carbon Finance in Rangelands

69 ECA Trade-offs Among Ecosystem Services in the Lake Victoria Basin.

69. The last remnants of mega biodiversity in West Java and Banten: an in-depth exploration of RaTA (Rapid Land Tenure Assessment) in Mount Halimun-Salak National Park Indonesia

70. Le business plan d'une petite entreprise rurale de production et de commercialisation des plants des arbres locaux. Cas de quatre pépinières rurales au Cameroun.

71. Les unités de transformation des produits forestiers non ligneux alimentaires au Cameroun. Diagnostic technique et stratégie de développement Honoré Tabuna et Ingratia Kayitavu.

72. Les exportateurs camerounais de safou (Dacryodes edulis) sur le marché sous régional et international. Profil, fonctionnement et stratégies de développement.

73. Impact of the Southeast Asian Network for Agroforestry Education (SEANAFE) on agroforestry education capacity.

74. Setting landscape conservation targets and promoting them through compatible land use in the Philippines.

75. Review of methods for researching multistrata systems.

76. Study on economical viability of Jatropha curcas L. plantations in Northern Tanzania assessing farmers' prospects via cost-benefit analysis

77. Cooperation in Agroforestry between Ministry of Forestry of Indonesia and International Center for Research in Agroforestry

78. "China's bioenergy future. an analysis through the Lens if Yunnan Province

79. Land tenure and agricultural productivity in Africa: A comparative analysis of the economics literature and recent policy strategies and reforms

80. Boundary organizations, objects and agents: linking knowledge with action in Agroforestry watersheds

81. Reducing emissions from deforestation and forest degradation (REDD) in Indonesia: options and challenges for fair and efficient payment distribution mechanisms 
82. Mainstreaming climate change into agricultural education: challenges and perspectives

83. Challenging conventional mindsets and disconnects in conservation: the emerging role of ecoagriculture in Kenya's landscape mosaics

84. Lesson learned RATA garut dan bengkunat: suatu upaya membedah kebijakan pelepasan kawasan hutan dan redistribusi tanah bekas kawasan hutan

85. The emergence of forest land redistribution in Indonesia

86. Commercial opportunities for fruit in Malawi

87. Status of fruit production processing and marketing in Malawi

88. Fraud in tree science

89. Trees on farm: analysis of global extent and geographical patterns of agroforestry

90. The springs of Nyando: water, social organization and livelihoods in Western Kenya

91. Building capacity toward region-wide curriculum and teaching materials development in agroforestry education in Southeast Asia

92. Overview of biomass energy technology in rural Yunnan (Chinese - English abstract)

93. A pro-growth pathway for reducing net GHG emissions in China

94. Analysis of local livelihoods from past to present in the central Kalimantan Ex-Mega Rice Project area

95. Constraints and options to enhancing production of high quality feeds in dairy production in Kenya, Uganda and Rwanda

2010

96. Agroforestry education in the Philippines: status report from the Southeast Asian Network for Agroforestry Education (SEANAFE)

97. Economic viability of Jatropha curcas L. plantations in Northern Tanzania- assessing farmers' prospects via cost-benefit analysis.

98. Hot spot of emission and confusion: land tenure insecurity, contested policies and competing claims in the central Kalimantan Ex-Mega Rice Project area

99. Agroforestry competences and human resources needs in the Philippines

100. CES/COS/CIS paradigms for compensation and rewards to enhance environmental Services

101. Case study approach to region-wide curriculum and teaching materials development in agroforestry education in Southeast Asia

102. Stewardship agreement to reduce emissions from deforestation and degradation (REDD): Lubuk Beringin's Hutan Desa as the first village forest in Indonesia

103. Landscape dynamics over time and space from ecological perspective

104. Komoditisasi atau koinvestasi jasa lingkungan: skema imbal jasa lingkungan program peduli sungai di DAS Way Besai, Lampung, Indonesia

105. Improving smallholders' rubber quality in Lubuk Beringin, Bungo district, Jambi province, Indonesia: an initial analysis of the financial and social benefits

106. Rapid Carbon Stock Appraisal (RACSA) in Kalahan, Nueva Vizcaya, Philippines

107. Tree domestication by ICRAF and partners in the Peruvian Amazon: lessons learned and future prospects in the domain of the Amazon Initiative eco-regional program

108. Memorias del Taller Nacional: "Iniciativas para Reducir la Deforestación en la region Andino Amazónica", 09 de Abril del 2010. Proyecto REALU Peru

109. Percepciones sobre la Equidad y Eficiencia en la cadena de valor de REDD en Perú -Reporte de Talleres en Ucayali, San Martín y Loreto, 2009. Proyecto REALU-Perú. 
110. Reducción de emisiones de todos los Usos del Suelo. Reporte del Proyecto REALU Perú Fase 1

111. Programa Alternativas a la Tumba-y-Quema (ASB) en el Perú. Informe Resumen y Síntesis de la Fase II. 2da. versión revisada

112. Estudio de las cadenas de abastecimiento de germoplasma forestal en la amazonía Boliviana

113. Biodiesel in the Amazon

114. Estudio de mercado de semillas forestales en la amazonía Colombiana

115. Estudio de las cadenas de abastecimiento de germoplasma forestal en Ecuador http://dx.doi.org10.5716/WP10340.PDF

116. How can systems thinking, social capital and social network analysis help programs achieve impact at scale?

117. Energy policies, forests and local communities in the Ucayali Region, Peruvian Amazon

118. NTFPs as a Source of Livelihood Diversification for Local Communities in the Batang Toru Orangutan Conservation Program

119. Studi Biodiversitas: Apakah agroforestry mampu mengkonservasi keanekaragaman hayati di DAS Konto?

120. Estimasi Karbon Tersimpan di Lahan-lahan Pertanian di DAS Konto, Jawa Timur

121. Implementasi Kaji Cepat Hidrologi (RHA) di Hulu DAS Brantas, Jawa Timur. http://dx.doi.org/10.5716/WP10338.PDF

122. Kaji Cepat Hidrologi di Daerah Aliran Sungai Krueng Peusangan, NAD,Sumatra http://dx.doi.org/10.5716/WP10337.PDF

123. A Study of Rapid Hydrological Appraisal in the Krueng Peusangan Watershed, NAD, Sumatra. http://dx.doi.org/10.5716/WP10339.PDF

2011

124. An Assessment of farm timber value chains in Mt Kenya area, Kenya

125. A Comparative financial analysis of current land use systems and implications for the adoption of improved agroforestry in the East Usambaras, Tanzania

126. Agricultural monitoring and evaluation systems

127. Challenges and opportunities for collaborative landscape governance in the East Usambara Mountains, Tanzania

128. Transforming Knowledge to Enhance Integrated Natural Resource Management Research, Development and Advocacy in the Highlands of Eastern Africa http://dx.doi.org/10.5716/WP11084.PDF

129. Carbon-forestry projects in the Philippines: potential and challenges The Mt Kitanglad Range forestcarbon development http://dx.doi.org10.5716/WP11054.PDF

130. Carbon forestry projects in the Philippines: potential and challenges. The Arakan Forest Corridor forest-carbon project. http://dx.doi.org10.5716/WP11055.PDF

131. Carbon-forestry projects in the Philippines: potential and challenges. The Laguna Lake Development Authority's forest-carbon development project. http://dx.doi.org/10.5716/WP11056.PDF

132. Carbon-forestry projects in the Philippines: potential and challenges. The Quirino forest-carbon development project in Sierra Madre Biodiversity Corridor http://dx.doi.org10.5716/WP11057.PDF

133. Carbon-forestry projects in the Philippines: potential and challenges. The Ikalahan Ancestral Domain forest-carbon development http://dx.doi.org10.5716/WP11058.PDF

134. The Importance of Local Traditional Institutions in the Management of Natural Resources in the Highlands of Eastern Africa. http://dx.doi.org/10.5716/WP11085.PDF 
135. Socio-economic assessment of irrigation pilot projects in Rwanda. http://dx.doi.org/10.5716/WP11086.PDF

136. Performance of three rambutan varieties (Nephelium lappaceum L.) on various nursery media. http://dx.doi.org/10.5716/WP11232.PDF

137. Climate change adaptation and social protection in agroforestry systems: enhancing adaptive capacity and minimizing risk of drought in Zambia and Honduras http://dx.doi.org/10.5716/WP11269.PDF

138. Does value chain development contribute to rural poverty reduction? Evidence of asset building by smallholder coffee producers in Nicaragua http://dx.doi.org/10.5716/WP11271.PDF

139. Potential for biofuel feedstock in Kenya. http://dx.doi.org/10.5716/WP11272.PDF

140. Impact of fertilizer trees on maize production and food security in six districts of Malawi. http://dx.doi.org/10.5716/WP11281.PDF

\section{2}

141. Fortalecimiento de capacidades para la gestión del Santuario Nacional Pampa Hermosa:

Construyendo las bases para un manejo adaptativo para el desarrollo local. Memorias del Proyecto. http://dx.doi.org/10.5716/WP12005.PDF

142. Understanding rural institutional strengthening: A cross-level policy and institutional framework for sustainable development in Kenya http://dx.doi.org/10.5716/WP12012.PDF

143. Climate change vulnerability of agroforestry http://dx.doi.org/10.5716/WP16722.PDF

144. Rapid assesment of the inner Niger delta of Mali http://dx.doi.org/10.5716/WP12021.PDF

145. Designing an incentive program to reduce on-farm deforestationin the East Usambara Mountains, Tanzania http://dx.doi.org/10.5716/WP12048.PDF

146. Extent of adoption of conservation agriculture and agroforestry in Africa: the case of Tanzania, Kenya, Ghana, and Zambia http://dx.doi.org/10.5716/WP12049.PDF

147. Policy incentives for scaling up conservation agriculture with trees in Africa: the case of Tanzania, Kenya, Ghana and Zambia http://dx.doi.org/10.5716/WP12050.PDF

148. Commoditized or co-invested environmental services? Rewards for environmental services scheme: River Care program Way Besai watershed, Lampung, Indonesia. http://dx.doi.org/10.5716/WP12051.PDF

149. Assessment of the headwaters of the Blue Nile in Ethiopia. http://dx.doi.org/10.5716/WP12160.PDF

150. Assessment of the uThukela Watershed, Kwazaulu. http://dx.doi.org/10.5716/WP12161.PDF

151. Assessment of the Oum Zessar Watershed of Tunisia. http://dx.doi.org/10.5716/WP12162.PDF

152. Assessment of the Ruwenzori Mountains in Uganda. http://dx.doi.org/10.5716/WP12163.PDF

153. History of agroforestry research and development in Viet Nam. Analysis of research opportunities and gaps. http://dx.doi.org/10.5716/WP12052.PDF

154. REDD+ in Indonesia: a Historical Perspective. http://dx.doi.org/10.5716/WP12053.PDF

155. Agroforestry and Forestry in Sulawesi series: Livelihood strategies and land use system dynamics in South Sulawesi http://dx.doi.org/10.5716/WP12054.PDF

156. Agroforestry and Forestry in Sulawesi series: Livelihood strategies and land use system dynamics in Southeast Sulawesi. http://dx.doi.org/10.5716/WP12055.PDF

157. Agroforestry and Forestry in Sulawesi series: Profitability and land-use systems in South and Southeast Sulawesi. http://dx.doi.org/10.5716/WP12056.PDF

158. Agroforestry and Forestry in Sulawesi series: Gender, livelihoods and land in South and Southeast Sulawesi http://dx.doi.org/10.5716/WP12057.PDF 
159. Agroforestry and Forestry in Sulawesi series: Agroforestry extension needs at the community level in AgFor project sites in South and Southeast Sulawesi, Indonesia. http://dx.doi.org/10.5716/WP12058.PDF

160. Agroforestry and Forestry in Sulawesi series: Rapid market appraisal of agricultural, plantation and forestry commodities in South and Southeast Sulawesi. http://dx.doi.org/10.5716/WP12059.PDF

\section{3}

161. Diagnosis of farming systems in the Agroforestry for Livelihoods of Smallholder farmers in Northwestern Viet Nam project http://dx.doi.org/10.5716/WP13033.PDF

162. Ecosystem vulnerability to climate change: a literature review. http://dx.doi.org/10.5716/WP13034.PDF

163. Local capacity for implementing payments for environmental services schemes: lessons from the RUPES project in northeastern Viet Nam http://dx.doi.org/10.5716/WP13046.PDF

164. Seri Agroforestri dan Kehutanan di Sulawesi: Agroforestry dan Kehutanan di Sulawesi: Strategi mata pencaharian dan dinamika sistem penggunaan lahan di Sulawesi Selatan http://dx.doi.org/10.5716/WP13040.PDF

165. Seri Agroforestri dan Kehutanan di Sulawesi: Mata pencaharian dan dinamika sistem penggunaan lahan di Sulawesi Tenggara http://dx.doi.org/10.5716/WP13041.PDF

166. Seri Agroforestri dan Kehutanan di Sulawesi: Profitabilitas sistem penggunaan lahan di Sulawesi Selatan dan Sulawesi Tenggara http://dx.doi.org/10.5716/WP13042.PDF

167. Seri Agroforestri dan Kehutanan di Sulawesi: Gender, mata pencarian dan lahan di Sulawesi Selatan dan Sulawesi Tenggara http://dx.doi.org/10.5716/WP13043.PDF

168. Seri Agroforestri dan Kehutanan di Sulawesi: Kebutuhan penyuluhan agroforestri pada tingkat masyarakat di lokasi proyek AgFor di Sulawesi Selatan dan Tenggara, Indonesia. http://dx.doi.org/10.5716/WP13044.PDF

169. Seri Agroforestri dan Kehutanan di Sulawesi: Laporan hasil penilaian cepat untuk komoditas pertanian, perkebunan dan kehutanan di Sulawesi Selatan dan Tenggara http://dx.doi.org/10.5716/WP13045.PDF

170. Agroforestry, food and nutritional security http://dx.doi.org/10.5716/WP13054.PDF

171. Stakeholder Preferences over Rewards for Ecosystem Services: Implications for a REDD+ Benefit Distribution System in Viet Nam http://dx.doi.org/10.5716/WP13057.PDF

172. Payments for ecosystem services schemes: project-level insights on benefits for ecosystems and the rural poor http://dx.doi.org/10.5716/WP13001.PDF

173. Good practices for smallholder teak plantations: keys to success http://dx.doi.org/10.5716/WP13246.PDF

174. Market analysis of selected agroforestry products in the Vision for Change Project intervention Zone, Côte d'Ivoire http://dx.doi.org/10.5716/WP13249.PDF

175. Rattan futures in Katingan: why do smallholders abandon or keep their gardens in Indonesia's 'rattan district'? http://dx.doi.org/10.5716/WP13251.PDF

176. Management along a gradient: the case of Southeast Sulawesi's cacao production landscapes http://dx.doi.org/10.5716/WP13265.PDF

177. Are trees buffering ecosystems and livelihoods in agricultural landscapes of the Lower Mekong Basin? Consequences for climate-change adaptation. http://dx.doi.org/10.5716/WP14047.PDF 
178. Agroforestry, livestock, fodder production and climate change adaptation and mitigation in East Africa: issues and options. http://dx.doi.org/10.5716/WP14050.PDF

179. Trees on farms: an update and reanalysis of agroforestry's global extent and socio-ecological characteristics. http://dx.doi.org/10.5716/WP14064.PDF

180. Beyond reforestation: an assessment of Vietnam's REDD+ readiness. http://dx.doi.org/10.5716/WP14097.PDF

181. Farmer-to-farmer extension in Kenya: the perspectives of organizations using the approach. http://dx.doi.org/10.5716/WP14380.PDF

182. Farmer-to-farmer extension in Cameroon: a survey of extension organizations. http://dx.doi.org/10.5716/WP14383.PDF

183. Farmer-to-farmer extension approach in Malawi: a survey of organizations: a survey of organizations http://dx.doi.org/10.5716/WP14391.PDF

184. Seri Agroforestri dan Kehutanan di Sulawesi: Kuantifikasi jasa lingkungan air dan karbon pola agroforestri pada hutan rakyat di wilayah sungai Jeneberang

185. Options for Climate-Smart Agriculture at Kaptumo Site in Kenyahttp://dx.doi.org/10.5716/WP14394.PDF

\section{5}

186. Agroforestry for Landscape Restoration and Livelihood Development in Central Asia http://dx.doi.org/10.5716/WP14143.PDF

187. "Projected Climate Change and Impact on Bioclimatic Conditions in the Central and South-Central Asia Region" http://dx.doi.org/10.5716/WP14144.PDF

188. Land Cover Changes, Forest Loss and Degradation in Kutai Barat, Indonesia. http://dx.doi.org/10.5716/WP14145.PDF

189. The Farmer-to-Farmer Extension Approach in Malawi: A Survey of Lead Farmers. http://dx.doi.org/10.5716/WP14152.PDF

190. Evaluating indicators of land degradation and targeting agroforestry interventions in smallholder farming systems in Ethiopia. http://dx.doi.org/10.5716/WP14252.PDF

191. Land health surveillance for identifying land constraints and targeting land management options in smallholder farming systems in Western Cameroon

192. Land health surveillance in four agroecologies in Malawi

193. Cocoa Land Health Surveillance: an evidence-based approach to sustainable management of cocoa landscapes in the Nawa region, South-West Côte d'Ivoire http://dx.doi.org/10.5716/WP14255.PDF

194. Situational analysis report: Xishuangbanna autonomous Dai Prefecture, Yunnan Province, China. http://dx.doi.org/10.5716/WP14255.PDF

195. Farmer-to-farmer extension: a survey of lead farmers in Cameroon. http://dx.doi.org/10.5716/WP15009.PDF

196. From transition fuel to viable energy source Improving sustainability in the sub-Saharan charcoal sector http://dx.doi.org/10.5716/WP15011.PDF

197. Mobilizing Hybrid Knowledge for More Effective Water Governance in the Asian Highlands http://dx.doi.org/10.5716/WP15012.PDF

198. Water Governance in the Asian Highlands http://dx.doi.org/10.5716/WP15013.PDF

199. Assessing the Effectiveness of the Volunteer Farmer Trainer Approach in Dissemination of Livestock Feed Technologies in Kenya vis-à-vis other Information Sources http://dx.doi.org/10.5716/WP15022.PDF

200. The rooted pedon in a dynamic multifunctional landscape: Soil science at the World Agroforestry Centre http://dx.doi.org/10.5716/WP15023.PDF 
201. Characterising agro-ecological zones with local knowledge. Case study: Huong Khe district, Ha Tinh, Viet Nam http://dx.doi.org/10.5716/WP15050.PDF

202. Looking back to look ahead: Insight into the effectiveness and efficiency of selected advisory approaches in the dissemination of agricultural technologies indicative of Conservation Agriculture with Trees in Machakos County, Kenya. http://dx.doi.org/10.5716/WP15065.PDF

203. Pro-poor Biocarbon Projects in Eastern Africa Economic and Institutional Lessons. http://dx.doi.org/10.5716/WP15022.PDF

204. Projected climate change impacts on climatic suitability and geographical distribution of banana and coffee plantations in Nepal. http://dx.doi.org/10.5716/WP15294.PDF

205. Agroforestry and Forestry in Sulawesi series: Smallholders' coffee production and marketing in Indonesia. A case study of two villages in South Sulawesi Province. http://dx.doi.org/10.5716/WP15690.PDF

206. Mobile phone ownership and use of short message service by farmer trainers: a case study of Olkalou and Kaptumo in Kenya http://dx.doi.org/10.5716/WP15691.PDF

207. Associating multivariate climatic descriptors with cereal yields: a case study of Southern Burkina Faso http://dx.doi.org/10.5716/WP15273.PDF

208. Preferences and adoption of livestock feed practices among farmers in dairy management groups in Kenya http://dx.doi.org/10.5716/WP15675.PDF

209. Scaling up climate-smart agriculture: lessons learned from South Asia and pathways for success http://dx.doi.org/10.5716/WP15720.PDF

210. Agroforestry and Forestry in Sulawesi series: Local perceptions of forest ecosystem services and collaborative formulation of reward mechanisms in South and Southeast Sulawesi http://dx.doi.org/10.5716/WP15721.PDF

211. Potential and challenges in implementing the co-investment of ecosystem services scheme in Buol District, Indonesia. http://dx.doi.org/10.5716/WP15722.PDF

212. Tree diversity and its utilization by the local community in Buol District, Indonesia http://dx.doi.org/10.5716/WP15723.PDF

213 Vulnerability of smallholder farmers and their preferences on farming practices in Buol District, Indonesia http://dx.doi.org/10.5716/WP15724.PDF

214. Dynamics of Land Use/Cover Change and Carbon Emission in Buol District, Indonesia http://dx.doi.org/10.5716/WP15725.PDF

215. Gender perspective in smallholder farming practices in Lantapan, Phillippines. http://dx.doi.org/10.5716/WP15726.PDF

216. Vulnerability of smallholder farmers in Lantapan, Bukidnon. http://dx.doi.org/10.5716/WP15727.PDF

217. Vulnerability and adaptive capacity of smallholder in Ho Ho Sub-watershed, north-central Viet Nam http://dx.doi.org/10.5716/WP15728.PDF 


The World Agroforestry Centre is an autonomous, non-profit research organization whose vision is a rural transformation in the developing world as smallholder households increase their use of trees in agricultural landscapes to improve food security, nutrition, income, health, shelter, social cohesion, energy resources and environmental sustainability. The Centre generates science-based knowledge about the diverse roles that trees play in agricultural landscapes, and uses its research to advance policies and practices, and their implementation that benefit the poor and the environment. It aims to ensure that all this is achieved by enhancing the quality of its science work, increasing operational efficiency, building and maintaining strong partnerships, accelerating the use and impact of its research, and promoting greater cohesion, interdependence and alignment within the organization.

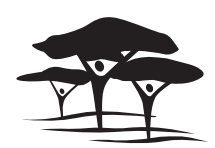

United Nations Avenue, Gigiri • PO Box 30677 • Nairobi, $00100 \cdot$ Kenya Telephone: +254 207224000 or via USA +1 6508336645 Fax: +254207224001 or via USA +16508336646 Email: worldagroforestry@cgiar.org•www.worldagroforestry.org

Southeast Asia Regional Program • Sindang Barang • Bogor 16680 PO Box $161 \cdot$ Bogor $16001 \cdot$ Indonesia

Telephone: +62 $2518625415 \cdot$ Fax: +62 2518625416 